\title{
Digital literacy for teachers in Cuban Tourism and Hotel Management Schools. Some experiences on its development
}

\author{
Raidell Avello Martínez ${ }^{1}$ and Raúl López Fernández ${ }^{2}$ \\ 1. University of Cienfuegos (UCf), Cuba | ravello@ucf.edu.cu \\ 2. Metropolitan University of Ecuador (UMET), Ecuador | rlopez@ucf.edu.cu
}

Submitted in: October 2013 Accepted in: February 2014 Published in: July 2015

\section{Recommended citation}

Avello, R., \& López, R. (2015). Digital literacy for teachers in Cuban Tourism and Hotel Management Schools. Some experiences on its development. RUSC. Universities and Knowledge Society Journal, 12(3). pp. 3-16. doi http://dx.doi.org/10.7238/rusc.v12i3.1994

\begin{abstract}
Digital literacy for teachers has been a widely studied topic in recent years, and several studies have been conducted featuring student-oriented ICT competency models and frameworks. This research aims to develop a teacher-oriented ICT Competency Framework for Cuban Tourism and Hotel Management School instructors, on the one hand, to have reference points or criteria to make an assessment on the actual status of ICT training and, on the other hand, to provide guidelines on ICT training for teachers. The main research method for this paper was document analysis. The proposed model states that ICT training for teachers has to be undertaken on a continuous basis. Incorporating new tools into the teachers' professional environment is a critical matter to be taken into consideration for any type of teacher training model in the 21st century. Furthermore, some examples on the main courses and training sessions that are part of the Teacher ICT Training Research Project are provided. It may be concluded that a teacher-oriented ICT Competency Framework for the context of Cuban Tourism and Hotel Management Schools was attained.
\end{abstract}

\section{Keywords}

digital literacy, digital literacy for teachers, teacher training in ICT, ICT competencies

\section{Alfabetización digital de los docentes de las escuelas de hotelería y turismo cubanas. Experiencias en su implementación}

\section{Resumen}

El tema de la alfabetización digital de los docentes ha sido estudiado extensamente en los últimos años. En estudios realizados acerca del tema se pueden encontrar diferentes modelos y marcos de competencias TIC dirigidas a los docentes. El propósito de este trabajo es elaborar un marco de competencias TIC dirigido a los docentes de las escuelas de hotelería y turismo cubanas que permita, por un lado, tener un referente de criterios para poder evaluar el estado actual de la preparación con respecto a las TIC, y por otro, orientar la formación en TIC de los docentes. El método de investigación fundamental fue el análisis de documentos. El modelo propuesto expresa que la formación en TIC de los docentes tiene que ser permanente. La incorporación de nuevas herramientas a su entorno de actuación, de manera crítica, tiene que ser un elemento presente en cualquier modelo de formación de los docentes del siglo xx. Además, se muestran ejemplos de cursos y entrenamientos, más destacados, que forman parte del proyecto de investigación Formación de los docentes en TIC. Se puede concluir que fue posible elaborar un marco de competencias TIC contextualizado dirigido a los docentes de las escuelas de hotelería y turismo cubanas.

\section{Palabras clave}

alfabetización digital, alfabetización digital de los docentes, formación de los docentes en TIC, competencias TIC 


\section{Introduction}

New education models and paradigms are increasingly being put forward by research papers and education experts in 21st-century society. The need to update teachers and train them to address the current challenges posed by the information and knowledge culture within their teaching practice has produced several reforms and studies in various countries (Carneiro, Toscano, \& Díaz, 2012).

In this scenario, digital literacy has been a widely studied topic in recent years (Bawden, 2008; Gutiérrez, 2010; Avello, López, Cañedo, Álvarez, Granados, \& Obando, 2013a). In general, various theoretical models (Eshet-Alkalai, 2012) and frameworks (Guitert \& Romeu, 2009; Gobierno Vasco, 2012; Riel, Christian, \& Hinson, 2012; Ferrari, 2013) for ICT competency may be found in the available literature. These proposed some new competencies needed by any individual in order to perform in the digital environments emerging nowadays.

Some proposals oriented particularly towards teachers were found (Prendes, 2010; Ministerio de Educación, 2011; UNESCO, 2011; Area, Gutiérrez, \& Vidal, 2012; Prendes \& Gutiérrez, 2013), revealing that teacher training in ICT (or as stated by Gutiérrez (2008), the (now-digital) "new literacy campaign" for educators) is an increasingly important topic worldwide, and is being addressed in various ways and from various viewpoints. However, it is worth highlighting that this has not been true for all regions, especially in Latin America (Sunkel \& Trucco, 2012), where extensive teacher training in ICT programs and continuous follow-up thereof are still needed, as posed by the dynamics of technological development.

Cuban Tourism and Hotel Management Schools have fostered ICT training for teachers within this scenario. It began with courses on the Microsoft Office Suite and later on, when networking was introduced, other courses were developed on the use of e-mail, Internet browsing and webpage design, among others (Avello et al., 2013a). Due to the moment when they were delivered and the quick development of ICT, these courses turned out to be insufficient, and lost their usefulness because, among other reasons, they took place before the 2006/2007 period. This was the period when the social web emerged and developed at a fast pace, and users (i.e., students) began taking more leadership, since the levels of interactivity and network collaboration were increased.

Some years later, during the 2011/2012 academic year, the Teacher ICT Training Project was created and designed in Perla del Sur Tourism and Hotel Management School. This project aimed to refocus and reorganize teacher digital literacy, taking into account both worldwide experiences and the criteria provided by specialists in this field as well as the teachers themselves.

This paper aims to develop an ICT Competency Framework for Cuban Tourism and Hotel Management School teachers on the basis of the above-mentioned Project's guidelines, starting with a review of various proposals found in the literature in order to guide teacher training in ICT and retaining points of reference and criteria for its assessment. Additionally, some comments are provided on the outcomes obtained from the first training actions that were taken in parallel to the drafting of the Framework.

\section{Main references found in the literature}

A teacher is no longer a beacon of knowledge, but rather a pathfinder who assists students in using the tools and resources they need to explore and attain new skills and pieces of knowledge (Páez, 2008; De la Torre \& Domínguez, 2012). Therefore, in such an ever-changing environment, educators (just like any other type 
of professional) need continuous updating in order to avoid joining the ranks of the "digitally illiterate" (Area, Gutiérrez, \& Vidal, 2012).

This digital literacy campaign cannot be limited to procedural knowledge on the use of ICT. As stated by Valerio and Valenzuela (2011), more than mere skills are required to use a piece of software or to operate a digital device: one needs to master a wide range of complex cognitive, motive, social, emotional and methodological skills in order to perform effectively in any digital environment (Freitas, 2010; Eshet-Alkalai, 2012). Teaching programs therefore depend on their significance as well as on teachers' motivation, disposition, training and competencies (Miratía, 2012). This process should not rely only upon teachers' willingness, but also on the level of organization, planning and control undertaken by their relevant educational institutions as part of their strategy.

The ICT competencies required by teachers in this modern information and knowledge society were summarized over a decade ago in Cabero (1999), Tejada (1999), Majó and Marqués (2000) and Marqués (2000) as follows:

- Displaying a positive attitude towards ICT as a set of cultural instruments convenient for many personal and professional activities.

- Awareness of the various uses of ICT in the context of education.

- Awareness of the use of ICT in their relevant knowledge field.

- Skillful use of ICT in their activities: text processors, e-mail, web browsing.

- Integrating ICT into their curricula as a normal practice when planning (e.g., ICT as a set of tools in the scope of their activities within their own field of knowledge, as a didactic means and a vehicle for cognitive development).

- Coming up with training actions involving ICT use by students.

- Evaluating the use of ICT.

As may be noted, these competencies — clustered in dimensions, i.e., technical, professional updating, teaching methodology and behavior - are basically oriented towards technological and didactic factors, and to a lesser degree towards training researchers by using ICT.

Area (2007), in Rangel and Peñalosa (2013), states that a complete teaching model for literacy in the use of ICT must consider the simultaneous development of four training areas or dimensions: procedural, cognitive, behavioral and axiological. This model has an evidently theoretical character, which makes it difficult to be directly implemented and, being a general proposal, it fails to address specific matters relevant to the teaching activity.

In 2008, the International Society for Technology in Education launched in the US the National Educational Technology Standards (NETS) for Teachers (ISTE, 2008), which are focused on the level of training that teachers need to undergo in order to effectively incorporate information technology into their teaching practice and into the various communicative, professional and collaborative activities in which they are involved.

As per Cabero (2004), these standards are strongly related to the competencies and abilities learners of different ages need when dealing with ICT. Therefore, many of these issues were taken into account when building the Competency Framework, since it is students who will benefit from a better training for teachers.

On the other hand, the results in Garzón's doctoral research (2009) display a digital literacy model for university lecturers based on an empirical study conducted at the Autonomous University of Chiapas (UNACH), Mexico. This model is based on four core components, as per Figure 1: (i) institutional management, (ii) technological 
infrastructure, (iii) university curriculum and (iv) lecturers and their training. This model has a rather organizational nature and contains some factors to be taken into account when planning and implementing digital literacy for teachers

Figure 1. Digital literacy model for lecturers at UNACH

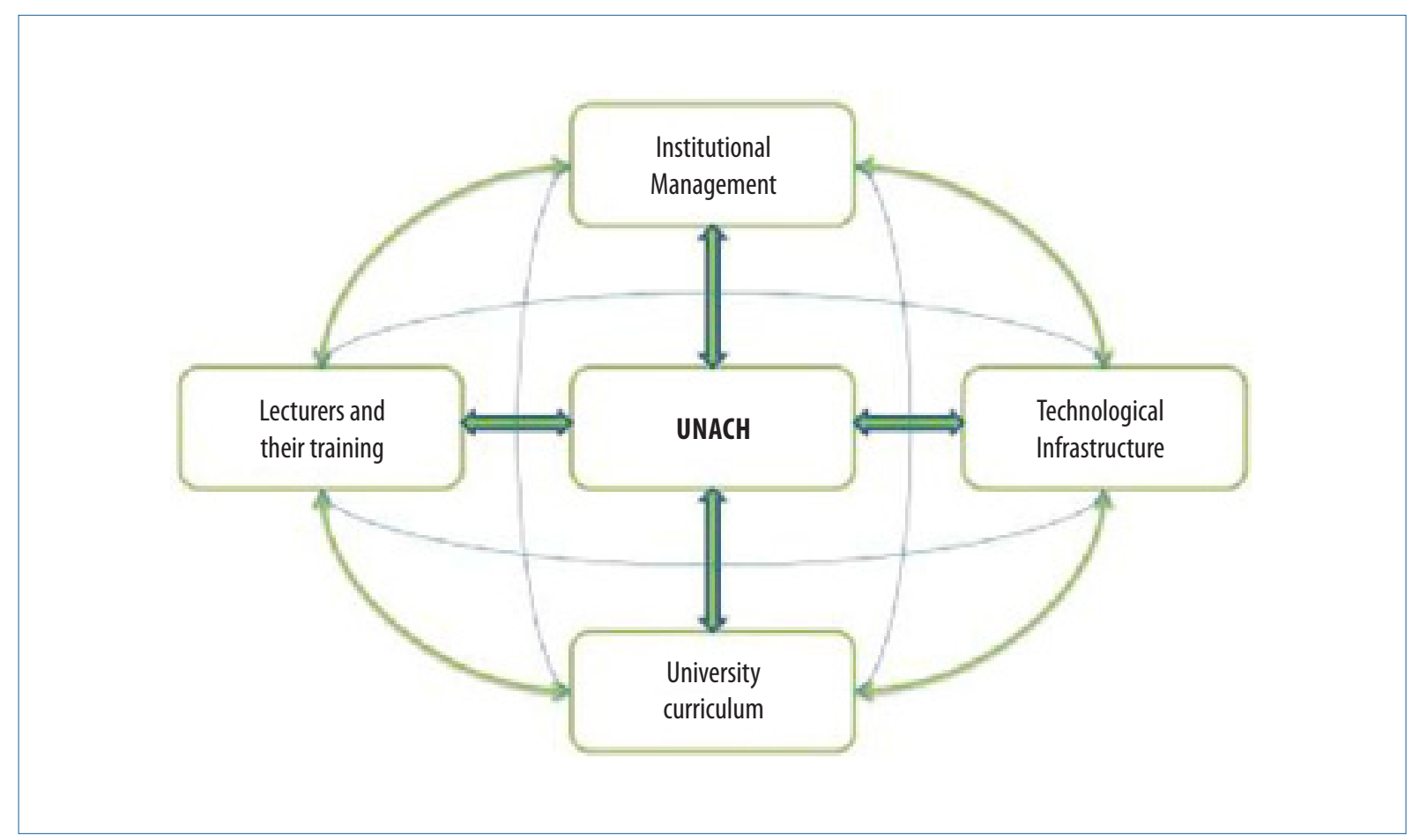

In 2008, UNESCO released the ICT Competency Framework for Teachers (ICT-CFT), seeking to establish useful criteria and parameters for teacher training in the context of ICT and to help standardize teacher competencies in this area for the future. The project included guidelines for curricula, pedagogy, the competencies to be developed by students and teacher training.

This report was updated in 2011 as a result of ongoing cooperation efforts among UNESCO, Cisco, Intel, ISTE and Microsoft (UNESCO, 2011). The document in question features three modules for ICT competencies: (i) Technology literacy, (ii) Knowledge deepening for creative, complex problem solving and (iii) Knowledge creation to enhance innovation abilities using ICT to take advantage of knowledge itself. Furthermore, the study contains six areas or dimensions, which makes it quite broad. However, its subject matter is poorly allocated into the six dimensions, and it was found that it targets educators at all levels, in some of which research is not envisaged as a key component.

On the other hand, there is the project called Competencias TIC para la docencia en la universidad pública española: indicadores y propuestas para la definición de buenas prácticas (ICT Competencies for teaching in Spanish Public Universities: indicators and proposals for defining best practices), which has been financed by the Spanish Ministry of Education (reference EA2009-0133) and is intended to improve quality both for higher education teaching and for the activities of university lecturers (Prendes, 2010). 
This project involved lecturers from various universities in Spain and its main goal was the drafting of a catalog of indicators on ICT competencies for university lecturers. This was based on the information provided to several local and international quality agencies as well as Spanish universities (Prendes \& Gutiérrez, 2013).

As a result of this broad research, a structured model was proposed for organizing ICT competencies into three basic areas, consistent with the three basic professional performance areas for teachers — teaching, research and management. However, it must be noted that the area relating to research only has two indicators and, therefore, we consider that it should be further expanded, considering our teachers' considerable volume of research activity.

Seeking to effectively integrate ICT into the teaching, technical and educational institutions' management processes, the Chilean Education Ministry launched in 2006 the ICT Competency Framework for Teachers, which was updated later on in 2011 pursuant to the advances of the social web, also called Web 2.0 (Ministerio de Educación, 2011).

This study provides an overview of the identified ICT competencies, clustered in five dimensions:

- The teaching dimension

- The technical or procedural dimension

- The management dimension

- The social, ethical and legal dimension

- The professional responsibility and development dimension

According to the authors themselves, dimensions give rise to competencies, from which criteria emerge, and then the latter are standardized. They also state that a 'standard' is a competency that has turned into a valid reference for a given group, the Chilean Education Sector in this case. This set of standards, in spite of being teacheroriented in general, is applicable to our context provided that, in addition to these standards, certain specific issues are considered, such as the ones relating to research.

For its part, the Basque Government released a report called Mapas TIC para la capacitación digital del profesorado y alumnado del País Vasco (ICT Maps for digital literacy in students and teachers in the Basque Country), drafted as part of the Eskola 2.0 program (2009-2013) by the Basque Government Department of Education, Universities and Research.

The above-mentioned work is based on the six dimensions proposed by NETS 2008, which were re-clustered in three dimensions:

- Fluency with technology

- Learning - knowledge

- Digital citizenship

Each of these dimensions clusters a series of sub-competencies and, for each one, evaluation criteria are highlighted, since they are considered to be specific tasks that students should be able to perform.

Finally, there is the empirical study conducted by Rangel and Peñalosa (2013), where some results on the digital literacy of lecturers are provided. For their purposes, they built an instrument based on a competency profile 
organized into three dimensions: technology, information and teaching. When assessing this proposal, it may be ascertained that research-related competencies are integrated into all dimensions, mainly into the one relating to information, which in our opinion biased the results to a certain extent.

In short, by reviewing the referenced literature, several proposals oriented towards teachers at various education levels can be found. Most comprise a range between three and six dimensions or areas, and two or three domain levels. Likewise, some proposals of a more theoretical nature aimed at modeling competencies are available, as are others of a more practical nature aimed at the implementation of training. During our analysis, our attention was drawn to the fact that, in general, few proposals include the area relating to research within ICT competencies for teachers, whereas others consider it as integrated into other dimensions.

\section{An ICT Competency Framework for Cienfuegos Tourism and Hotel Management School (EHTCF)}

In order to draft the first version of the ICT Competency Framework for teachers in the Cuban Tourism and Hotel Management Schools, the following methods were used:

Document Analysis. Over 15 proposals, models and competency frameworks were reviewed, out of which the 9 referenced in the paragraph above were analyzed in depth.

Group Discussions. Group discussions were held by 6 professors distributed as follows: 2 professors from the EHTCF, 2 invited professors from other Tourism Schools and 2 lecturers from the University of Cienfuegos (UCf), Cuba, acting as consultants.

As a result, an ICT competency organization framework was drafted on the basis of three dimensions: (i) technology, (ii) teaching and (iii) professional-research development, as may be noted in Table 1. This framework was intended to be built in a practical, contextualized and simple manner to enable rapid understanding and implementation, and to reinforce the area relating to research, since this was one of the deficiencies found in the studied references and is not consistent with our setting.

Dimensions were defined as follows:

The technology dimension is based on issues relating to interaction with technology, effective performance in digital environments, and efficient communication and collaboration with other users. Other topics related to information security were added, which are certainly a must these days.

The teaching dimension comprises aspects relating to interaction, implementation and collaboration in e-learning environments, drafting and re-drafting learning resources by various means, as well as applying new didactic strategies that take advantage of ICT resources and seek to develop critical, creative and innovative behaviors in students.

The professional-research development dimension includes aspects for addressing information relevant to their field of knowledge, creating and participating in virtual research networks and also publishing their scientific and intellectual production.

Each of these dimensions clusters competencies in two domain levels: (i) level 1 (usage), related to knowledge, skills and values acting as support for the use of ICT, and (ii) level 2 (application-creation), including the competencies needed to design, implement and evaluate ICT actions with a reflective and critical outlook. 
Table 1. Digital literacy model for teachers

\begin{tabular}{|c|c|c|c|}
\hline \multirow{2}{*}{ Criteria } & \multicolumn{3}{|c|}{ Dimensions } \\
\hline & Technology & Teaching & Professional-research development \\
\hline $\begin{array}{l}\text { Level } 1 \\
\text { (Usage) }\end{array}$ & $\begin{array}{l}\text { Working with computer systems and } \\
\text { networks. } \\
\text { Managing devices. } \\
\text { Operating office software packages. } \\
\text { Being aware of security issues relevant } \\
\text { to IT equipment. } \\
\text { Searching, assessing, storing, sharing } \\
\text { and organizing information. } \\
\text { Using Web } 2.0 \text { tools (blogs, RSS, wikis, } \\
\text { social networks, etc.). } \\
\text { Being aware of copyright and licensing } \\
\text { issues. }\end{array}$ & $\begin{array}{l}\text { Interacting in e-learning } \\
\text { environments. } \\
\text { Participating as a student in } \\
\text { learning activities involving digital } \\
\text { environments. } \\
\text { Using digital resources as support } \\
\text { for teaching, learning and curricular } \\
\text { management processes. }\end{array}$ & $\begin{array}{l}\text { Using reference management software, } \\
\text { such as Zotero, Endnote, etc. to store and } \\
\text { use information. } \\
\text { Using Web } 2.0 \text { tools to participate in } \\
\text { discussions and exchanges with teachers } \\
\text { and researchers within their own } \\
\text { discipline. } \\
\text { Being aware of the impact of ICT on the } \\
\text { subject field they teach. }\end{array}$ \\
\hline $\begin{array}{l}\text { Level } 2 \\
\text { (Application } \\
\text { - creation) }\end{array}$ & $\begin{array}{l}\text { Solving network, connectivity and } \\
\text { Internet security problems. } \\
\text { Managing digital identities. } \\
\text { Creating, capturing and editing digital } \\
\text { images and videos. } \\
\text { Developing webpages and multimedia } \\
\text { presentations. }\end{array}$ & $\begin{array}{l}\text { Implementing virtual environments } \\
\text { and learning experiences. } \\
\text { Drafting and/or re-drafting learning } \\
\text { resources by various means: } \\
\text { tutorial videos, audio, infographics, } \\
\text { etc. } \\
\text { Applying new didactic strategies in } \\
\text { the classroom to take advantage of ICT } \\
\text { resources. } \\
\text { Creating collaborative learning } \\
\text { environments by using Web } 2.0 \text { tools } \\
\text { (blogs, RSS, wikis, social networks, } \\
\text { etc.). } \\
\text { Applying methods that foster } \\
\text { developmental learning through } \\
\text { ICT. }\end{array}$ & $\begin{array}{l}\text { Creating and publishing personal } \\
\text { libraries. } \\
\text { Creating or actively participating in } \\
\text { virtual networks dedicated to research. } \\
\text { Creating environments for research and } \\
\text { development by using Web } 2.0 \text { tools } \\
\text { (blogs, RSS, wikis, social networks, etc.). } \\
\text { Publishing their scientific and } \\
\text { intellectual production. }\end{array}$ \\
\hline
\end{tabular}

Source: Own elaboration

It should be noted that, within the selected competencies, "Participating as a student in learning activities involving digital environments" was included since most of our teachers, due to their age and other factors, have not participated as students in courses involving the use of education technology, which limits their perspective for understanding their students' learning process in courses delivered through e-learning environments, for instance. Furthermore, this phenomenon occurs on an ongoing basis, since, in order to include new teaching tools, it is paramount that teachers learn first not only about the tools, but also through them.

Figure 2 is a graphic representation of the intrinsically cyclic nature of the implementation of the developed framework, as well as its relationship with the learning processes proposed by Benjamin Bloom and tailored by 2009 by Andrew Churches for the digital era (Churches, 2009). It becomes evident that ICT training for teachers has to be undertaken on a continuous basis. Incorporating new tools into the teachers' professional environment is a critical matter to be taken into consideration for any type of teacher training model in the 21st century, and this is based on one of the principles proposed by UNESCO: lifelong learning. 
Figure 2. Cyclic nature of the model and its relationship with learning processes

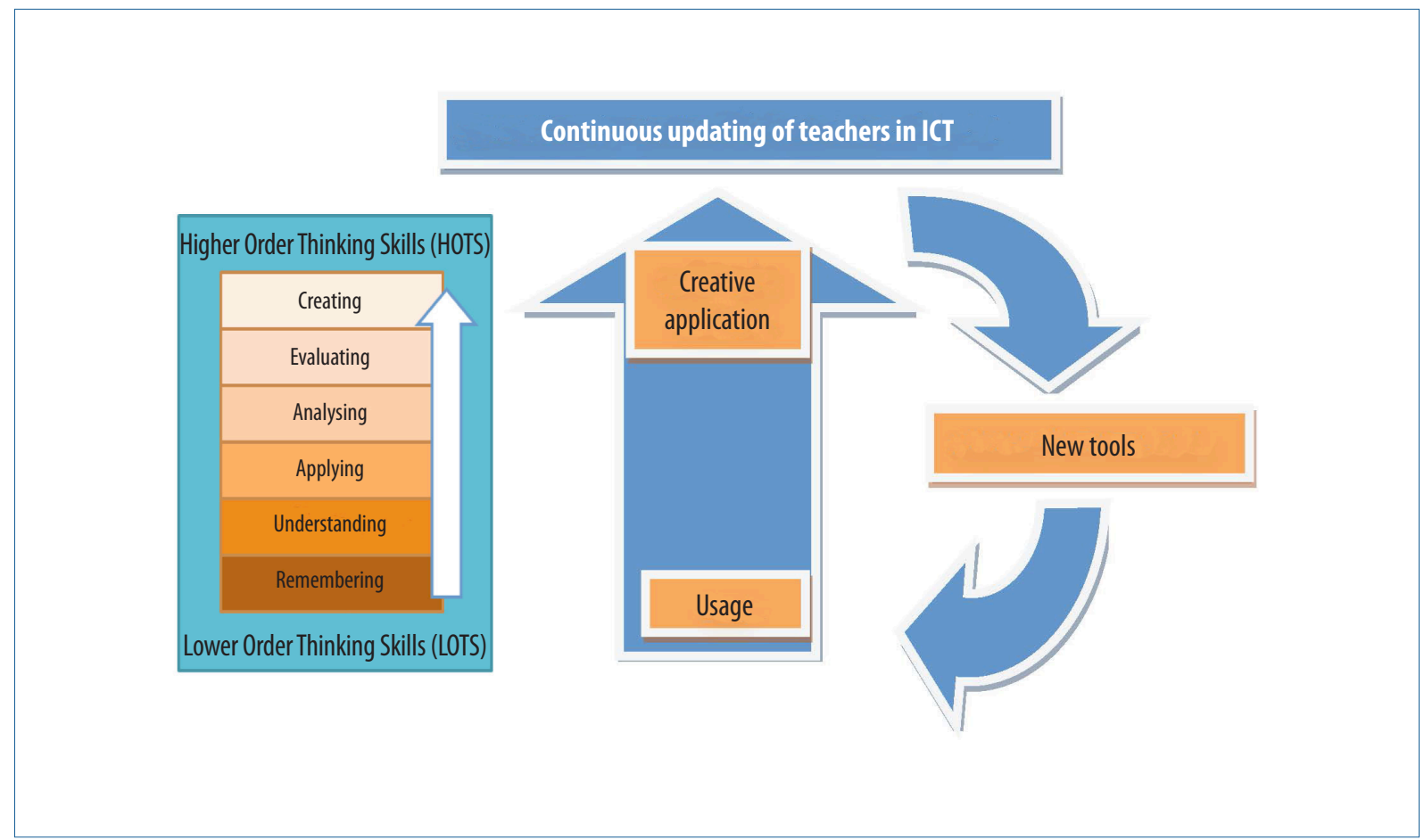

In order to draft the competencies, the authors took on the general conception of competency proposed by Gairín (2011): "the coordinated activation and application of various elements in order to address actual professional situations", as well as the approximation to general competency in teachers made by Tejada (2009): "delivering, tutoring and assessing training actions by developing and using didactic means and resources, promoting quality in training and didactic updating".

\section{Developments in digital literacy for teachers at the EHTCF}

In the Perla del Sur Tourism and Hotel Management School of Cienfuegos (EHTCF ), a series of courses and training sessions have been delivered by the IT professors as part of the Research Project for Teacher Training in ICT, registered in the EHTCF in 2011.

This project aims to provide teachers with training and updating on ICT. For this purpose, in the first working year, a first draft of an ICT Framework was produced, aimed at guiding ICT training for teachers. This was the framework introduced in the paragraph above. In parallel to the drafting of the Framework and in order to buy some time, training actions in this regard were undertaken; these were based on learning needs assessments that teachers are required to make on an annual basis.

The main results obtained from two of the training actions already completed, mainly consistent with the teaching and professional-research development dimensions within the developed Framework, are shown below. 


\section{Training in Information Technology}

This training in Information Technology contains the following modules: (i) searching for and retrieving information from the web, (ii) organizing information through Zotero (iii) and publishing research. This action is clearly consistent with the professional-research development dimension.

The main goal of this training session was to improve the drafting process of both graduate and postgraduate level research papers in relation to referencing, citing and organizing the references.

Twenty-three teachers participated in the three modules and achieved positive evaluations.

In order to assess the result of this training, during the subsequent tutoring process the research papers from the past two years were checked for inconsistencies in referencing, use of bibliography and compliance with the referencing standard. Additionally, a questionnaire was applied to ask teachers' opinions about the convenience of using Zotero for the drafting of research papers and theses by their students. These results are available in Avello, Martín, Díaz, \& Clavero (2013b).

However, some remarks of acceptance by the teachers are given below:

"... it was easy to comply with the required referencing standard, the process being automatic once the standard was entered into Zotero."

"... it is very convenient to add citations during the thesis drafting process itself, and then Zotero inserts them directly in the References section, where they are shown already in alphabetical order or following whatever standard was selected."

\section{Introduction to the Moodle Platform}

This introductory course to the Moodle Platform features four topics and comprises the teaching dimension; it was delivered during the 2011/2012 academic year.

The goal of this course was to design distance-learning courses through the Moodle Platform and also start incorporating Web 2.0 tools into such courses, with the aim of achieving a higher level of leadership by and interaction among students. This was intended to widen the range of distance courses offered and improve the quality of the existing ones.

Sixteen teachers participated and achieved positive evaluations.

After completion of the course and a reasonable period of 6 months had elapsed, it was ascertained that 8 of the participants were able to set up and deliver their courses via the platform; the courses of the remaining 50\%, were still incomplete, although it is worth highlighting that the overall quality in all of them had increased. For instance, one of the courses resulted in a professor achieving her master's degree in ICT applied to Education from the University of Cienfuegos (UCf), Cuba.

With regards to the other goal of the course, i.e., teachers incorporating Web 2.0 tools into their courses, such as wikis, discussion forums, blogs, RSS feeds, etc., it was verified that few courses included these features. It should be noted, however, that this was due mainly to issues with technology, restrictions and access rights. 


\section{Conclusions}

Continuous training and updating for teachers is one of the challenges in the 21st century and also one of the goals set out by Tourism and Hotel Management Schools in Cuba. In the light of this prospect, it may be asserted that some steps are already being taken and some accomplishments are being made.

On analyzing the studied proposals, along with their dimensions, competencies, criteria, levels, etc., it became evident that little attention is being given to the area relating to research, which is very important for our teachers, since they have as many hours dedicated to research as to teaching in their plans. Therefore, a first draft of the teacher-oriented ICT Competency Framework is proposed, with three dimensions: (i) technology, (ii) teaching and (iii) professional-research development, as well as two domain levels. This Framework clearly offers integral training and more accurate planning of training and self-training actions intended for teachers in Cuban Tourism and Hotel Management Schools.

On the other hand, this Framework also provides the criteria needed for ongoing evaluation of teachers' ICT competencies in their various dimensions, which may undergo modifications, since this framework will undoubtedly have to be reviewed and updated at least every two years in order to keep up with the fast developments in ICT.

It is concluded that the implementation of the proposed framework for ICT training or digital literacy for teachers needs to be cyclical and continuous. Incorporating new tools, such as social web or Web 2.0 applications, into the teachers' professional environment is a critical matter to be taken into consideration for any type of teacher training model in the 21 st century.

The results from the courses show that the first teacher training actions had some impacts, mainly on the research and teaching areas. Obviously, these actions will be re-organized and planned on the basis of the Framework, which will ensure that training responds to a greater extent to the competencies required by the modern information society.

The results obtained lead to further research work, which mainly includes performing qualitative and quantitative analyses to examine teachers' competencies as per the proposed Framework, and integrating this Framework into the Overall Training Strategy for Tourism and Hotel Management Schools in the country, for which some steps were already being taken at the time this paper was submitted.

Likewise, teaching and learning trends and approaches must not be overlooked while training teachers in ICT nowadays. To this end, there are significant reports available, such as the NMC Horizon Report: 2013 Higher Education Edition (NMC, 2013), drafted by the New Media Consortium (NMC), and the EDUCAUSE Learning Initiative (ELI). Its aim is to identify new technologies that will have impacts on the fields of teaching, learning, research and creative expression in Higher Education over the next five years (Sangrà, 2012), and it must be seen as a resource for regular consultation by any teacher who wants to keep up to date with developments brought about by ICT in society and particularly in education. 


\section{References}

Area, M., Gutiérrez, A., \& Vidal, F. (2012). Alfabetización digital y competencias informacionales. Madrid: Fundación Telefónica. Retrieved from https://ddv.ull.es/users/manarea/public/libro_\%20Alfabetizacion_digital.pdf

Avello Martínez, R., López Fernández, R., Cañedo Iglesias, M., Álvarez Acosta, H., Granados Romero, J., \& Obando Freire, F. (2013a). Evolución de la alfabetización digital: nuevos conceptos y nuevas alfabetizaciones. Medisur, 11(4). Retrieved from http://www.medisur.sld.cu/index.php/medisur/article/view/2467

Avello Martínez, R., Martín, I., Díaz, M., \& Clavero, M. I. (2013b). Zotero, más allá de un gestor bibliográfico. Una experiencia con los docentes y nuevas metas. Revista Didáctica, Innovación y Multimedia, 25. Retrieved from http://dim.pangea.org/revistaDIM25/revista25ARzotero.htm

Bawden, D. (2008). Origins and concepts of digital literacy. In C. Lankshear \& M. Knobel (Eds.), Digital literacies: Concepts, Policies and Practices (pp. 17-32). New York, NY: Peter Lang Publishing.

Cabero, J. (2004). Formación del profesorado en TIC. El gran caballo de batalla. Comunicación y Pedagogía. Nuevas tecnologías y recursos didácticos, 195, 27-31.

Cabero, J. (2004, December). Formación del profesorado en TIC. Paper presented at II Congreso Nacional de Formación del Profesorado en Tecnologías de la Información y la Comunicación, Jaén, Spain.

Carneiro, R., Toscano, J., \& Díaz, T. (2012). Los desafíos de las TIC para el cambio educativo. Madrid: OEl \& Fundación Santillana.

Churches, A. (2009). Taxonomía de Bloom para la era digital. Eduteka. Retrieved from http://www.eduteka.org/TaxonomiaBloomDigital.php

De la Torre Navarro, L. M., \& Domínguez Gómez, J. (2012). Las TIC en el proceso de enseñanza aprendizaje a través de los objetos de aprendizaje. Revista Cubana de Informática Médica, 4(1), 83-92.

Eshet-Alkalai, Y. (2012). Thinking in the Digital Era: A Revised Model for Digital Literacy. Issues in Informing Science and Information Technology, 9, 267-276.

Ferrari, A. (2013). DIGCOMP: A Framework for Developing and Understanding Digital Competence in Europe. Luxemburgo: Publications Office of the European Union. Retrieved from http://ftp.jrc.es/EURdoc/JRC83167.pdf

Freitas, M. (2010). Letramento digital e formação de professores. Educação em Revista, 26(03), $335-352$. doi: http://dx.doi.org/10.1590/S0102-46982010000300017

Gairín, J. (2011). Formación de profesores basada en competencias. Bordón. Revista de Pedagogía, 63(1), 93-108.

Garzón, R. (2009). Modelo de alfabetización digital para profesores universitarios a partir de un estudio empírico de la Universidad Autónoma de Chiapas (Doctoral dissertation). Universidad de Salamanca, Salamanca.

Gobierno Vasco. (2012). Competencia en el tratamiento de la información y competencia digital. Marco teórico. Bilbao: Departamento de Educación, Universidad e Investigación.

Guitert, M., \& Romeu, T. (2009). A digital literacy proposal in online Higher Education: the UOC scenario. eLearning Papers, 12.

Gutiérrez, A. (2008). Las TIC en la formación del maestro. «Realfabetización» digital del profesorado. Revista Interuniversitaria de Formación de Profesorado, 22(3), 191-206.

Gutiérrez, A. (2010). Creación multimedia y alfabetización en la era digital. In Aparici, R. (coord.). Educomunicación: más allá del 2.0 (pp. 171-186). Barcelona: Gedisa Editorial.

ISTE. (2008). National Educational Technology Standards for Teachers (Second Edition). United States: International Society for Technology in Education. 
Marqués, P. (2000). Los docentes: Funciones, roles, competencias necesarias, formación. Informally published, Retrieved from http://www.uaa.mx/direcciones/dgdp/defaa/descargas/docentes_funciones.pdf

Ministerio de Educación. (2011). Competencias TIC para la profesión docente. Chile: Ministerio de Educación. Retrieved from www.enlaces.cl

Miratía, O. J. (2012). Necesidades de formación en los docentes universitarios en relación a las herramientas web 2.0. @tic. revista d'innovació educativa, 9, 71-78. doi: http://dx.doi.org/10.7203/attic.9.1951

NMC. (2013). Horizon Report 2013. Higher Education Edition. The New Media Consortium. Retrieved from http://www.nmc.org/pdf/2013-horizon-report-HE.pdf

Páez, H. (2008). Alfabetización digital para docentes de postgrado. Revista Paradigma, XXIX(2), 07-34.

Prendes, M. P. (2010). Competencias TIC para la docencia en la Universidad Pública Española: Indicadores y propuestas para la definición de buenas prácticas: Programa de Estudio y Análisis (Informe de proyecto N. EA2009-0133). Universidad de Murcia: Secretaría de Estado de Universidades e Investigación. Retrieved from http://www.um.es/ competenciastic/informe_final_competencias2010.pdf.

Prendes, M. P., \& Gutiérrez, I. (2013). Competencias tecnológicas del profesorado en las universidades españolas. Revista de Educación, 361. doi: http://dx.doi.org/10-4438/1988-592X-RE-2011-361-140

Rangel, A., \& Peñalosa, E. A. (2013). Alfabetización digital en docentes de educación superior: Construcción y prueba empírica de un instrumento de evaluación. Píxel-Bit. Revista de Medios y Educación, 43, 9-23. doi: http://dx.doi. org/10.12795/pixelbit.2013.i43.01

Riel, J., Christian, S., \& Hinson, B. (2012, March). Charting digital literacy: A framework for information technology and digital skills education in the community college. Paper presented at Innovations 2012, Philadelphia, PA.

Sangrà, A. (2012, June). Horizon Report Iberoamérica y Gestión del Conocimiento. Paper presented at XIII Encuentro Internacional Virtual Educa Panamá 2012, Panamá.

Sunkel, G., \& Trucco, D. (2012). Las tecnologías digitales frente a los desafíos de una educación inclusiva en América Latina. Algunos casos de buenas prácticas. Santiago de Chile: Comisión Económica para América Latina y el Caribe (CEPAL). Retrieved from www.cepal.org/publicaciones/xml/4/48484/LasTecnologiasDigitales.pdf

Tejada, J. (2009). Competencias docentes. Profesorado. Revista de curriculum y formación del profesorado, 13(2), 1-15. UNESCO. (2011). Marco de competencias TIC para los docentes (Second Edition). Paris: Ediciones de la Organización de las Naciones Unidas para la Educación, la Ciencia y la Cultura. Retrieved from http://unesdoc.unesco.org/ images/0021/002134/213475E.pdf

Valerio, G., \& Valenzuela, J. (2011). Competencias informáticas para el e-learning 2.0. Revista Iberoamericana de Educación a Distancia, 14(1), 137-160.

RUSC VOL. 12 No 3 | Universitat Oberta de Catalunya and University of New England | Barcelona, July, 2015 


\section{About the authors}

Raidell Avello Martínez

ravello@ucf.edu.cu

Auxiliary Professor, University of Cienfuegos (UCf), Cuba

Raidell Avello is an auxiliary professor in the Department of Informatics at the University of Cienfuegos (UCf), Cuba. PhD student in Education Science at the UCf. He holds a master's degree in Applied Mathematics. He is an active researcher focusing on education technology, ICT training for teachers and digital literacy. He serves on the editorial board of various international journals and on the program committees of international conferences in his field of research, such as RUSC. Universities and Knowledge Society Journal; Didáctica, Innovación y Multimedia; Journal of Information Technology Education: Research (JITE: Research); InSITE: Informing Science + IT Education Conferences, among others. (http://ravellom.blogspot. com).

Universidad de Cienfuegos Carlos Rafael Rodríguez

Vicerrectorado de Investigación y Posgrado

Carretera a Rodas Km 4, Cuatro Caminos

Cienfuegos, CP 59430

Cuba

\section{Raúl López Fernández}

rlopez@ucf.edu.cu

Senior Professor and Advisor to the Vice-Rector for Research and Postgraduate Studies, University of Cienfuegos (UCf),

Cuba; Professor of Mathematics and Research Methods, Metropolitan University of Ecuador (UMET)

Former vice-rector at the University of Medical Sciences, Cienfuegos, Cuba. He has participated in accreditation processes for undergraduate studies and master's degree programs. Visiting scholar at the University of Guayaquil, Ecuador, from June to September 2012. He won a scholarship to the Education Science Faculty in Asturias, Spain, and delivered a series of lectures at the University of the Basque Country. He is the head of the Research Methods Module for the Higher Medical Education master's degree program at the Dr Raúl Dorticós Torrado Medical Science Faculty of Cienfuegos. He is an associate professor at the IEPC in Asturias, Spain. He is a reviewer for the Medisur journal in Cienfuegos, Cuba (www. medisur.sld.cu). He is the secretary of the Scientific Advisory Council for the Universidad y Sociedad journal in Cienfuegos, Cuba (http://www.ucf.edu.cu/ojsucf/index.php/uys).

Universidad de Cienfuegos Carlos Rafael Rodríguez

Vicerrectorado de Investigación y Posgrado

Carretera a Rodas Km 4, Cuatro Caminos

Cienfuegos, CP 59430

Cuba

Original title: Alfabetización digital de los docentes de las escuelas de hotelería y turismo cubanas. Experiencias en su implementación 


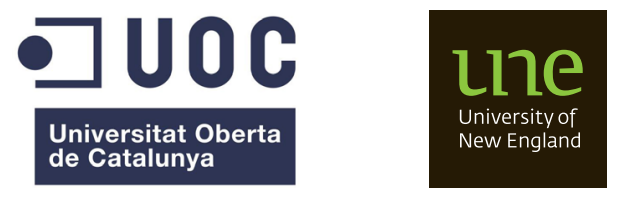

